\title{
City branding in Indonesia: The urgency of public communication, involvement, and inter-sectoral collaboration
}

\author{
Forina Lestari ${ }^{1}$, Melasutra MD Dali ${ }^{2}$, Norbani Che- $-\mathrm{Ha}^{3}$ \\ ${ }^{1}$ Department of Urban and Regional Planning, Institute Technology of Indonesia \\ ${ }^{2}$ Department of Urban and Regional Planning, Faculty of Built Environment, University Malaya \\ ${ }^{3}$ Department of Marketing, Faculty of Business and Accountancy, University Malaya \\ Correspondence: Melasutra MD Dali (email: melasutr@um.edu.my)
}

Received: 17 January 2020; Accepted: 14 April 2020; Published: 30 May 2020

\begin{abstract}
Contemporary cities are facing various challenges, both internally and externally. Indonesian cities are not exempted from this phenomenon. In light of this, city branding has become a widespread practice undertaken by most city managers to attract visitors, tourists, and investors. This study is trying to capture the city branding implementation in Indonesia and suggests several improvement strategies in tourism development. This study is using content analysis to explore existing literature on city branding implementation in several cities in Indonesia over the last ten years. A summary of more than thirty studies is provided along with the content analysis. The finding of these studies gives a significant contribution to the field of city branding that focuses on practical operational in social and governance dimensions in the local context. It shows that the limitation of understanding on city branding concept from the local authorities in many cities has resulted in less efficient and effective branding. City branding in most cities in Indonesia was trapped merely in making slogan and logos with less consideration in public aspirations and local identities. In addition, the common problem of lack of intersectoral coordination has resulted in a situation where branding has been undertaken solely by the tourist management sectors without proper support from other sectors. This study emphasizes the urgency of public involvement and inter-sectoral collaboration in ensuring city branding successfulness.
\end{abstract}

Keywords: city branding, collaboration, Indonesia, public involvement, tourism

\section{Introduction}

The concept of city branding is increasingly popular among researchers and practitioners in the world. It is driven by the fierce competition in attracting investors, tourists, and visitors in the globalized world. The potential and attractive place will be able to attract those resources and ultimately will increase economic growth and welfare in the region. The competition has encouraged the local government to adopt branding strategies in urban development policy to compete with other cities in the world. The extent to which city branding encompasses is not only slogan and logo but also included other guidelines and strategies related to physic and 
non-physic aspects such as culture, community, environment, and economy (Kokkranikal, Cronje, \& Butler, 2011).

Nowadays, new approaches to city branding have been differentiating cities with products. Cities, unlike products, are living entities that are dynamic. Concomitantly, in the practice of city branding, researchers observed that some cities such as Dubai and Beijing, have been successfully attracting worldwide attention without using general branding tools, such as slogans and logos. Their governments, instead, have been focusing on policy improvements, innovative strategies, and community engagements (Sevcik, 2011). It indicates that an immediate process of building good imagery and reputation through merely slogans are not applicable to cities, or places in general. A comprehensive approach needs to be taken into account in branding the cities, involving planning, policies, programs, and stakeholders' collaboration (Kokkranikal et al., 2011; Loho \& Braun, 2014).

Previous research has been undertaken to explore the relationship between city branding and tourism development in several contexts (see, for example, Kokkranikal, 2011; Dredge, 2003; Go, 2012; Hosany, 2006). Place branding has become one of the most popular concepts in the field of marketing places in general and tourist destinations in particular (Avraham \& Ketter, 2008). Nevertheless, it is found that research in the context of Indonesia is quite rare. It is interesting, not only because Indonesia is the largest country in the Southeast Asian region, but also due to some indications on the widespread usage of city branding in attracting tourism in this country.

According to Miller (2013), Indonesian cities have been relatively late in implementing city branding. In fact, the opportunity for the city governments to engage in city branding is increasing, particularly in the era of decentralization. With the enactment of the Law 32/2004 of the Local Governments (which then updated by the Law 23/2014 on the same matter) and the Law 33/2004 on the Local Budgets, municipalities and regencies are being given more authorities both in income generation and expenditure. Cities now are being actively promoting the place's potential as a means to increase their income and to improve the residents' welfare. It is a prospective development, yet a challenging one. Having more than 90 administrative cities and more than 500 urban areas, with various cultural values, ample options are available for these city managers to employ city branding to attract local and foreign investments. Nevertheless, the limited capabilities of the local bureaucrats, in particular when dealing with progressive attitudes of investments, provide an obstacle. Moreover, it is not much research has been undertaken to guide the municipalities in implementing a good practice of city branding.

Therefore, the aim of this study is trying to review and to analyze the development of city branding in Indonesia through the use of city branding theoretical framework. Previous studies on the implementation of city branding in Indonesian cities are mainly on the base of single case studies. This paper provides a recapitulation of those previous studies (around thirty research) to gain insight into the general pattern of city branding in several Indonesian cities during the past ten years or so. Additionally, this study also analyses the pattern by the place branding concept, in particular, highlighting the importance of public involvement and the collaboration of inter-governmental sectors. It is widely perceived that the tourism sector is the only sector that is related to city branding in Indonesia. While it is true that significant impacts of city branding may have been influencing the tourism sector, city branding as a comprehensive strategy needs to involve other sectors as well. 


\section{Theoretical Framework}

Previous studies have reported cities are more and more in direct competition with each other. As a result of globalization, many services, people, and investments can move freely around the world, and they go to what is the most exciting, promising places. In this sense, a particular city is not only competing with its surrounding city but also with distant cities, sometimes not even on the same continent. In response to this, there has been an urgency for cities to promote themselves more actively (Kavaratzis \& Ashworth, 2005). Besides, the local level is also driven by the public and political awareness increasing in the face of global competition. According to Kavaratzis (2005), the development of place branding in the past few decades have demonstrated the proliferating phenomenon in many countries around the world to show their potential to other places.

A large and growing body of literature has investigated the basic concept of place branding. It has been borrowing the idea from product branding, which considers place as a product that has characteristics such as identity, differentiation, and personality (Hankinson, 2007). However, recent evidence suggests that the place is not as simple as products, which are static (Bouchon, 2013). Place consists of a set of dynamic people, so places are not a product; governments are not producers, and users are not consumers (Kavaratzis, 2005). Therefore, the acceptance and perception of the product and places are different because people are visiting heritage buildings, cultures, and communities that may have a variety of experiences.

Despite the importance of branding the cities, it is also found that many issues and research gaps should be faced in terms of the implementation of city brandings, such as stakeholder engagement (Go \& Trunfio, 2012) and local governments policy-making process (Braun, 2010). Therefore, it requires a proper identification of the problems and alternative strategies (Moilanen, 2015; Go, 2012). In reference to Bai (2010), it is known that most cities today in heavily on the usage of slogans and logos without proper attention to other aspects that are indirectly related to branding. For example, Braun \& Kavaratzis (2010) found that words of mouth (WOM), as well as the physical quality of cities, are far more critical in determining the success of branding strategy, as compared to slogans and logos. Besides, it has conclusively been shown that other policies are also essential in realizing the success of city branding. According to Marsh \& Fawcett (2011), there is a strong connection between city branding and politics because the policy constructed will be related to the policy-making process that involved many sectors and stakeholders. Braun (2011) also confirms that city branding should be viewed as a part of urban governance that related to city marketing and public administration. It is true, especially when looking at government administration and governance, where most of the policies are taking place. Branding the city, therefore, is not solely about making identities of cities, but also determining an appropriate approach in formulating policies to support the aim of the brands (Herezniak, Magdalena Florek, \& Anders-Morawska, 2015).

Besides, the implementation of a collaborative approach under local authorities is a crucial factor in developing competitive city brands. However, there is a consensus among researchers that successful city branding needs to be built on a consensus of the identity and core values of the city among city authorities and various stakeholders (Bai et al., 2010; García, Gómez, \& Molina, 2012; Hatch \& Schultz, 2010; M Kavaratzis et al., 2010; Rehmet \& Dinnie, 2013; Zenker, Braun, \& Petersen, 2017; Zouganeli, Trihas, Antonaki, \& Kladou, 2012). In addition, the engagement and supportive behavior of internal stakeholders are essential determinants to create a consistent city brand in the long-term. In this regard, brand orientation plays a vital role in understanding the identity of a city as branded by city authorities and the brand reality as experienced by stakeholders in the city. A strong brand 
should be established based on representative elements of a destination and on strategies that convey the unique and distinct meaning of the city brand (Morgan \& Pritchard, 2002).

In accommodating the notions above, this study is using Hankinson's brand orientation model as its theoretical framework (Figure 1A). The model proposes five elements of the brand: brand culture, brand departmental coordination, brand communication, brand reality, and brand partnership (Hankinson, 2012). As quoted in Hankinson (2012, p. 983), the definition of each element is as follow:

"Brand orientation is a managerial approach that puts the development and maintenance of brand identity at the center of marketing strategy and seeks to integrate an organization's processes around the implementation of that strategy. Brand reality refers to matching the brand experience to the brand promise. Brand culture relates to the organization's vision, beliefs, and values. Brand departmental coordination refers to a collection of specific activities that unite departments around the brand. Brand partnership refers to managing a brand in partnership with other organizations that deliver the brand experience."

These five elements of brand orientation are essential because these are the basis for determining the direction of strategy and implementation that will lead to brand performance (Hankinson, 2012). This model then supplemented by Ahn, Kim \& Lee (2016), who investigated and expanded the Hankinson model to several attributes, namely: brand commitment, brand citizenship, and brand pride. According to Ahn et al. (2016), as a result of the brand orientation model proposed by Hankinson (2012), brand commitment then emerges. Brand commitment is defined as the psychological attachment of residents to the city brand. Such commitment then leads to brand citizenship, resulting in voluntary activities to promote and support the brand. Finally, brand pride among residents may be achieved if the positive emotions toward the brand meet the success of the brand implementation (Figure 1B).

These two models can be further examined that the Hankinson model will be determined the brand performance and also the brand attributes proposed by Ahn et al. (2016). It can be said that if the attributes expressed by Ahn are weak, then there might be a problem with brand attributes put forward by Hankinson (2012). Ahn's attributes also emphasize the importance of society as one of the determinants of the success of place branding.

Freire (2007) also stresses the importance of local people in the process of branding. Overall, such process also recommends that the extent in which the community is being involved the branding process, which could affect the success of the process of place branding (Ahn, Kim, \& Lee, 2016; Eshuis, Klijn, \& Braun, 2014; M Kavaratzis et al., 2010). 


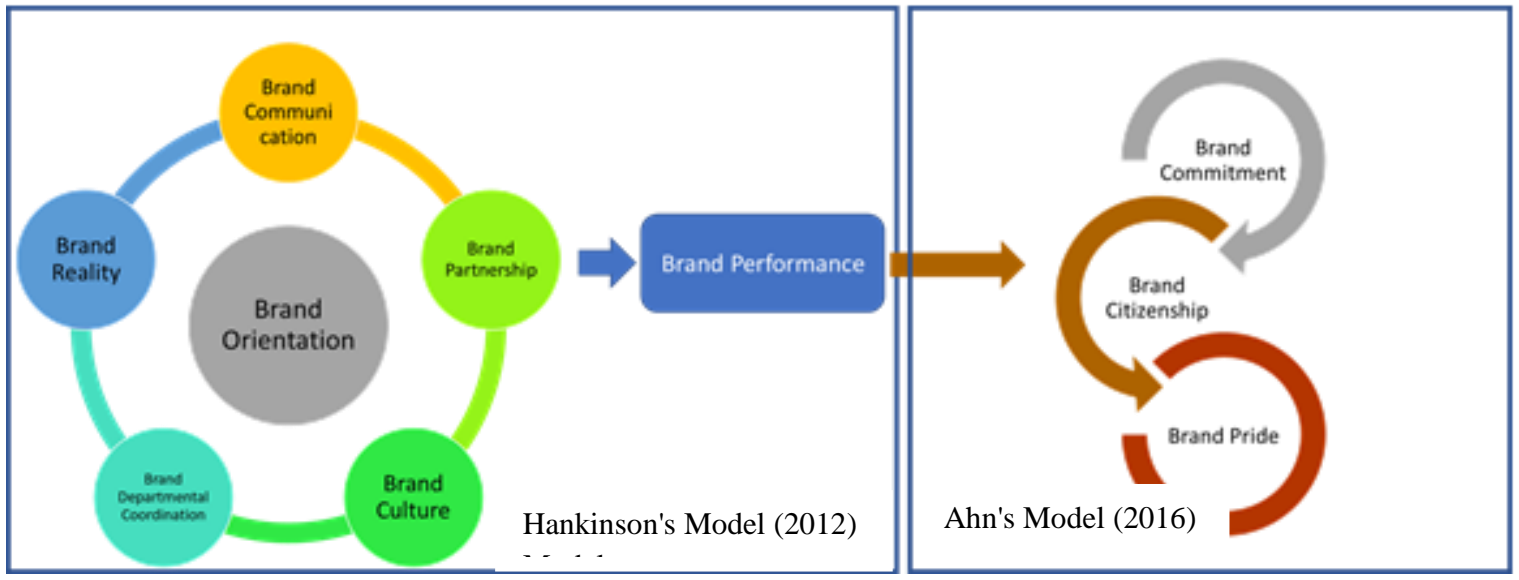

Figure 1. Brand orientation model (1A Hankinson's (2012) Model; 1B Ahn, Kim \& Lee's (2016) Model

\section{Methodology}

This paper is using content analysis to explore existing literature on city branding implementation in Indonesia. In this research, a text-based document (Mason, 1996) is used as data by compilating the previous study, describing, and comparing the result of their studies. As noted by Merriam (2009, p.150): "Using documentary material as data is not much different from using interviews or observations." Despite the limitations, these documents (personal papers) are an excellent source of data for numerous reasons such as easily accessible, free, contain information that might be could not be found in interviews or observation.

Around thirty articles, covering seven cities in Indonesia (Solo, Yogyakarta, Pasuruan, Jakarta, Surabaya, Banyuwangi, and Padang), were collected using keywords "city branding implementation in Indonesia." Content analysis is then performed. In order to maintain critical awareness based on critical judgments, articles collected then were classified in accordance with attributes provided by Hankinson's brand orientation model. The model is covering brand culture, brand reality, brand communication, departmental coordination, and public participation. In addition to that, Ahn et al. 's brand orientation model, including brand citizenship, pride, and commitment, are also used to further analyze these articles. A review of a national branding strategy is also outlined as a comparison with the regional branding strategies. A comprehensive list of challenges in the implementation of city branding and strategy to overcome them are also provided at the end of this article.

\section{Results and discussion}

\section{City branding implementation in Indonesia}

The development of branding in Indonesia started in the 1990s with the launch of "Visit Indonesia". Later, the brand was changed to "Wonderful Indonesia" in 2006. The existence of Law 32/2004 on decentralization increasingly opened the opportunity for the region to actively explored and developed its cities. The awareness of city branding has been seen with the proliferation of branding efforts through the city slogan and logo. For example, Jogjakarta with "Jogja, Never Ending Asia" wherein 2015 has been rebranded to "Jogja Istimewa", Bali as "Shanti Shanti Shanti", Solo "The Spirit of Java", Surabaya "Sparkling Surabaya" and 
Jakarta "Enjoy Jakarta". However, the branding process not supported by comprehensive policies, such as the provision of proper infrastructures and public facilities (Risanto, 2016).

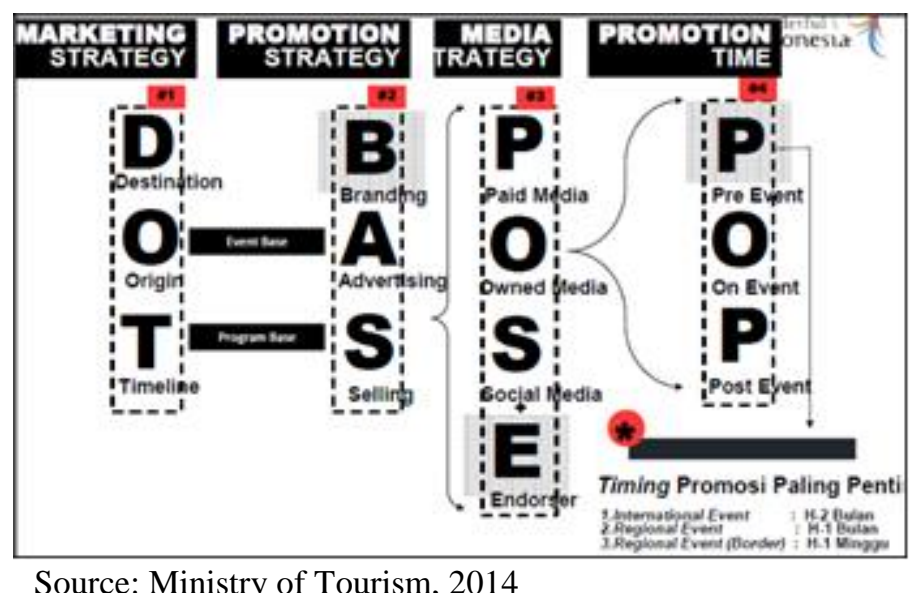

Figure 2. Comprehensive branding strategies

The tourism sector dominates the development of city branding in Indonesia because the brands are launched by the local tourism office that aims to attract tourists and investors. Tourism is a promising industry today, supported by the advance of technology, the increase of low-cost airlines, and the changes in people's lifestyles have encouraged the advancement of tourism in the world. Nevertheless, the city branding in Indonesia is a part of the promotion strategy solely conducted by tourism agencies (see Figure 2).

\begin{tabular}{|c|c|}
\hline $\begin{array}{c}\text { If BRANDING is a part of marketing, then } \\
\text { branding is : } \\
\text { Communication tool; }\end{array}$ & $\begin{array}{c}\text { If BRANDING is a WIDER of marketing, then } \\
\text { branding is : }\end{array}$ \\
$\begin{array}{c}\text { A strategic development tool; } \\
\text { A task for advertisers and graphic designers; } \\
\text { Disconnected from the place's identities; } \\
\text { Apolitical; }\end{array}$ & $\begin{array}{c}\text { A task for local authorities and stakeholder } \\
\text { planners; }\end{array}$ \\
Connected from the place's identities; \\
Effective in creating sense /pride of place \\
Effective in attracting investment \\
Ineffective in attracting investment \\
Effective in attracting visitors
\end{tabular}$\quad$\begin{tabular}{c} 
Effective in attracting, talent, people/ researchers \\
\hline
\end{tabular}

Source: Kalandides, Kavaratzis \& Ashworth, 2005

Figure 3. Types of branding in relation to marketing

Based on Figure 3, Lucarelli, Kalandides, \& Olof Berg (2011) and Kavaratzis \& Ashworth (2005) emphasize the differences in branding perspectives as a part of marketing strategy or broader than just marketing. Both of these perspectives have a significant impact on the implication of a branding strategy. For example, if branding is only undertaken as a part of marketing, it will not be effective in creating a sense of place and ineffective in attracting investment. It will only be effective in attracting tourists and visitors. Conversely, if branding has been in the broader position than just marketing, it will be a strategic development tool. It is vital because it will involve a significant change in government policies. The change brought by this particular approach is a comprehensive one that will be 
effective in attracting resources like an investment, tourism, and people. It indeed a big challenge for Indonesia to be able to position the branding in a collaborative level intersectoral governmental.

The following subsection provides an exploration of city branding strategies in several cities in Indonesia. The information is compiled on the basis of available studies. The analysis is arranged in accordance with the Brand Orientation Model put forward by Hankinson (2012).

\section{Testing The Brand Orientation Model: The Indonesian Context}

The first element of the Brand Orientation Model, "brand departmental coordination", refers to a collection of specific activities that unite departments around the brand. In Banyuwangi (Jannah, 2014) and Solo (Rahmanto, 2014), the branding process is merely a uni-sectoral program, involving only the tourism agencies. The policy implementation encountered many obstacles, such as the absence of branding performance monitoring, lack of understanding of government staff in city branding concepts, and the conflicting interests between agencies.

The element of brand reality aims to match the brand experience to the brand promise. Padang (Adona, 2014) and Solo cases show that the slogans and logos did not meet the reality of the cities' images and activities. In Surabaya, the slogan of "Sparkling Surabaya", for example, to promote and communicate the city image to a broader audience does not reflect the local identity and citizen perception (Oktavia \& Muliawan, 2009). It resulted in a lack of ownership from the local people. In 2015, Surabaya also held a competition regarding the rebranding of Surabaya city.

Brand culture element is closely related to the organization's vision, beliefs, and values. Based on a study conducted by Rahmanto (2014), city branding in Solo is undertaken by the local government without a specific strategic plan regarding the city brand. His investigation revealed that the branding of Solo city was merely a visual one. It was because both government and citizens did not understand the consequences of branding. It can be seen from the consistency of the slogan and logo, and there was no particular program to strengthen the brand identity. The policy formulation, in this case, ignores the understanding of technical and institutional dimensions. As a result, there are confusion and inconsistency towards the use of brand identity.

Brand communication element refers to communicating the brand to other stakeholders. In the case of Jogja city, the local government comes with the slogan "Jogja Never Ending Asia". However, eventually, the slogan was perceived to have no essential meaning, nt even inspiring people to come to Jogjakarta (Fortunata, 2014; Pasande \& Suhendra, 2017). Taking into account public criticisms, in 2014, the local government held a public invitation that aims to attract community aspiration related to Jogjakarta branding. In 2015, they changed the slogan to "Jogja Istimewa". Another example comes from Pasuruan city. Risanto (2016) provides an insight into how the management of branding undertaken by Pasuruan's local government was a lack of innovative strategies such as innovation regarding broadening media marketing.

Brand partnership element refers to managing a brand in collaboration with other organizations that deliver the brand experience. The development of city branding undertaken by the tourism department is still limited to the creation of slogans and logos, without considering public aspiration. A specific example can be seen in the case of Jogjakarta and Surabaya, where public criticism has led the local government to arrange the public hearing to rebrand the city. Ardyan (2016), in his research on tourist's perception of 
the Jakarta brand, emphasized the importance of the relationship between the city brand, people, and the tourist will determine the recommendation and revisit to the city.

The creation process of branding strategies undertaken by local governments, therefore, have been affecting the ownership of the slogans and logos by cities' residents. This phenomenon is pointed out by Ahn (2016) in the notions of "brand commitment," "brand citizenship," and "brand pride." Residents feel not being involved, and much of their aspirations have been likely ignored. Eventually, this leads to the performance of the cities brands. The models proposed by Hankinson (2012) and Ahn (2016), therefore, are quite useful in determining the problems of city branding implementation (Figure 4). In particular, it is clear that if there is a problem in Hankinson's attributes, it will cause the less optimal of the brand performance and also influence the Ahn's attributes (brand commitment, citizenship, and pride).

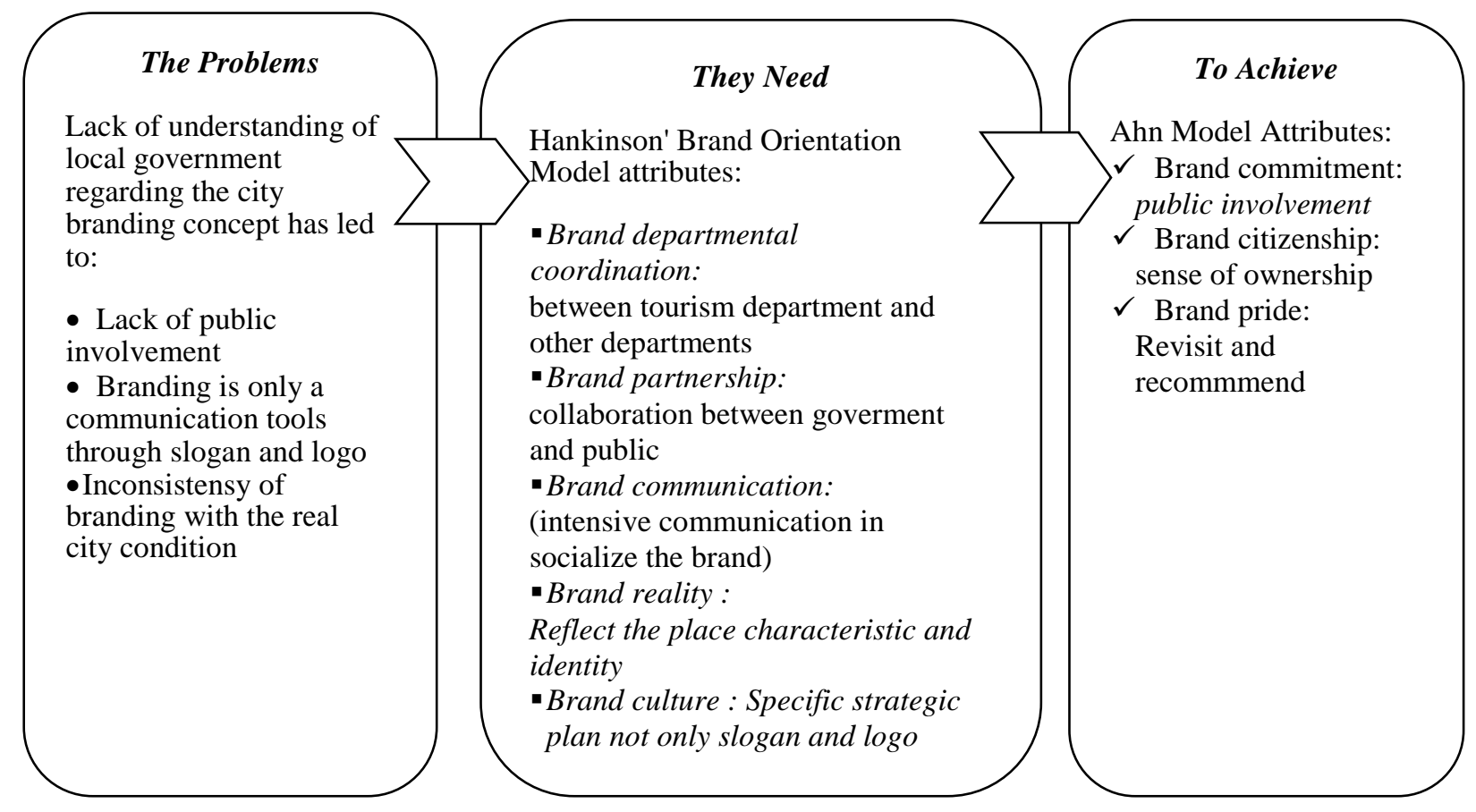

Figure 4. The relation of case studies and Hankinson's and Ahn's Model

The biggest challenge to be faced by cities in Indonesia today is establishing an acceptable city brand to all elements, as this will affect the community sense of ownership of the city branding and stakeholder involvement in the city branding process. In general, city branding in Indonesia is done partially, and not through a comprehensive study or stages (Pakarti, 2016). Limited understanding of local government in city branding concept that led to poor management of city branding regarding strategy formulation, funding allocation, and stakeholder coordination (Go \& Trunfio, 2012) are currently being faced by Indonesian cities., All of these challenges has been limiting the role of branding as only a part of marketing. In fact, branding in the aforementioned case studies seems only serves as communication tools trough slogans and logos instead of strategic tools from a collaboration between sectors in government. Therefore, it would not be optimal in attracting tourists, investment, and a sense of pride in the city.

Reflecting on the existing context in Indonesia, two things could be observed. First, overall, these studies highlight the fact that city branding in Indonesia is limited in the making slogan and logo. Nowadays, experts agree that brands are not just names given to 
products, especially places, because there are many things to consider. A strong collaborative partnership between government, private, and community are crucial to building an effective understanding and decision making (Rukayah, Wibowo, \& Wahyuningrum, 2015). Morgan (2002) adds that the long-term success of the brand is determined by the sense of belonging of its citizens toward the brand. Castelnovo, Misuraca, \& Savoldelli (2015) also argue that one of the core issues in smart city governance and policy decision making is how to involve the community as a vital role in the decision-making process, giving an active role in planning, implementation, and evaluation of the policies and programs undertaken. It implies that in the policy-making process, the role of the community must be highly regarded, not only through traditional approaches by drawing people's aspirations, but should also lead to a collaborative partnership. The trend shows that citizen participation and collaboration is no longer a difficult task to achieve since given the increasing development of Information and Technology, so people are getting smarter and more comfortable to access the latest information. Branding strategies nowadays require active communication between government and stakeholders, for example, by using the online communication media (Chaerani, 2011; Putro, Mayangsari, Siallagan, \& Novani, 2016; Somantri \& Budisetyorini, 2015). Nevertheless, it will also depend on government efforts to encourage stakeholder involvement.

Second, the collaboration between government agencies is essential in assuring the quality of various attributes of the city, such as infrastructure, public facilities, healthcare, social service, culture, safety level, environment, and education. In Indonesian, city branding is undertaken solely under the tourism sector management with a lack of proper support from other sectors (Hankinson, 2007; Risanto \& Yulianti, 2016). Ardyan (2016) adds that "the more qualified and interestingly attribute is developed by the city government, the more people are going to love the city" p14. In the Hankinson model, one of the attributes, namely departmental coordination, is a critical factor that will determine the brand performance. It will prove the extent to which other sectors support the city's brand. For example, if the slogan and logo issued by the tourism department and not backed up by other sectors such as public works that ensure the quality of transport and public facilities, then it will undoubtedly affect the public perception of the "brand reality." Another issue is the limited understanding of the local government officials on the concept of city branding could also lead to the ineffectiveness of the city branding process through inappropriate strategy undertaken. These two phenomena are observed at both the national and local levels.

\section{Conclusion}

Two concluding remarks can be observed in this study. The first one is related to the practice of city branding in Indonesia. The second one is related to the broader implementation of the city, or place, branding theoretical framework.

First, based on the result from city branding research in several Indonesian cities shows that the branding still limited to city promotion tools, which have not reflect the local identity characteristic, lack of community involvement, lack of integration policies between government agencies. In reality, the branding through slogan has not been followed by other policies such as transportation and facilities improvement. Therefore, upgrading efforts are needed to accompany the branding strategy with comprehensive programs that result in positive impacts on the city. City branding is not a commitment of the government only; they should invite all interested parties to participate in the city is committed to market the city. Private companies and residents (citizens) should be actively involved in becoming ambassadors for their cities. All sectors should work together to achieve the same goal 
through a comprehensive city branding strategy in urban development. Branding is also the task of all sector in city governance, and not only the responsibility of tourism agency. The development policy of cities is increasingly faced with various challenges involving many actors, agendas, and interests. The complexity of socioeconomic change requires enhanced capabilities that can follow the dynamic of demands from time to time.

Second, in the theoretical part, it is only a few kinds of literature on place branding have been addressing the city as the focus of the study. However, most of the literature has been referring to "place" in general. Contrary to such phenomena, this study provides input to brand performance, which is a significant factor in the success of city branding. When linked to the models proposed by Hankinson (2012) and Ahn (2016), this study proves that lack of a sense of community ownership of the city brand is indicated by the attributes of the Ahn model (brand commitment, brand citizenship, and brand pride) is due to the weak attributes as suggested by the Hankinson model (2012) namely departmental coordination, brand reality, brand culture, brand communication, and brand partnership. Therefore, the proposed further study is needed in evaluating more detail each attribute of both models in the local context.

This study presents a general overview and a review of city branding implementation in Indonesia. It is found that experience in major cities of Indonesia further strengthens the branding orientation model suggested by Hankinson (2012) and Ahn et al. (2016). In particular, it is highlighted that public participation and inter-sectoral collaboration are of importance in increasing citizen commitment and pride in citizenship. Future studies may consider elaboration in different countries to provide additional insight into the existing theoretical framework and literature.

\section{References}

Adinugroho, S., \& Mutiaz, I. R. (2012). Designing interactive digital media for Jakarta's historical sites as a medium for conservation and placemaking. Nirmana, 14(1), 3646.

Ahn, Y.J., Kim, I., \& Lee, T.J. (2016). Exploring visitor brand citizenship behavior: The case of the 'MICE city Busan', South Korea. Journal of Destination Marketing \& Management, 5(3), 249-259.

Avraham, E., \& Ketter, E. (2008). Media strategies for marketing places in crisis: Improving the image of cities, countries, and tourist destinations. Routledge.

Bai, X., McAllister, R. R. J., Beaty, R. M., \& Taylor, B. (2010). Urban policy and governance in a global environment: complex systems, scale mismatches, and public participation. Current Opinion in Environmental Sustainability, 2(3), 129-135. DOI: 10.1016/j.cosust.2010.05.008

Bouchon, F.A.,L. (2013). Truly Asia and a global city? Branding strategies and contested identities in Kuala Lumpur. Place Branding and Public Diplomacy, 10(1), 6-18. DOI: 10.1057/pb.2013.21

Braun, E. (2011). Putting city branding into practice. Journal of Brand Management, 19(4), 257-267. DOI: $10.1057 / \mathrm{bm} .2011 .55$

Castelnovo, W., Misuraca, G., \& Savoldelli, A. (2015). Smart cities governance: The need for a holistic approach to assessing urban participatory policy making. Social Science Computer Review, 34(6), 724-739. DOI: 10.1177/0894439315611103

Chaerani, R.Y. (2011). Pengaruh city branding terhadap city image (Studi Pencitraan Kota Solo:'The Spirit of Java'). JRK, 2(4). 
Ellisa, E. (2014). The entrepreneurial city of Kelapa Gading, Jakarta. Journal of Urbanism: International Research on Placemaking and Urban Sustainability, 7(2), 130-151. DOI: 10.1080/17549175.2013.875056

This, J., Klijn, E.-H., \& Braun, E. (2014). Place marketing and citizen participation: branding as a strategy to address the emotional dimension of policymaking? International Review of Administrative Sciences, 80(1), 151-171. DOI:10.1177/0020852313513872

Fortunata, S. (2014). Kajian pencitraan kota (City branding) Yogyakarta kesesuaian antara konseptual dan faktual berdasarkan media internet. Universitas Gadjah Mada.

Freire, J.R. (2007). 'Local People' a critical dimension for place brands. Journal of Brand Management, 16(7), 420-438. DOI: 10.1057/palgrave.bm.2550097

García, J.A., Gómez, M., \& Molina, A. (2012). A destination-branding model: An empirical analysis based on stakeholders. Tourism Management, 33(3), 646-661. doi: 10.1016/j.tourman.2011.07.006

Go, F.M., \& Trunfio, M. (2012). A paradigm shift from tourism destination management to democratic governance of place branding. Journal of Travel and Tourism Research (Online), 12(1), 4.

Green, A., Grace, D., \& Perkins, H. (2016). City branding research and practice: An integrative review. Journal of Brand Management, 23(3), 252-272. doi: $10.1057 / \mathrm{bm} .2016 .8$

Hall, C.M. (2014). Tourism and Social Marketing. Florence: Taylor and Francis.

Hankinson, G. (2007). The management of destination brands: Five guiding principles based on recent developments in corporate branding theory. Journal of Brand Management, 14(3), 240-254. doi: 10.1057/palgrave.bm.2550065

Hankinson, G. (2012). The measurement of brand orientation, its performance impact, and the role of leadership in the context of destination branding: An exploratory study. Journal of Marketing Management, 28(7-8), 974-999. doi: 10.1080/0267257X.2011.565727

Hatch, M.J., \& Schultz, M. (2010). Toward a theory of brand co-creation with implications for brand governance. Journal of Brand Management, 17(8), 590-604. doi: 10.1057/bm.2010.14

Herezniak, M., Magdalena Florek, D.M.G.D., \& Anders-Morawska, J. (2015). City brand strategy evaluation: in search of effectiveness indicators. Journal of Place Management and Development, 8(3), 187-205. doi: 10.1108/jpmd-06-2015-0023

Jannah, B. (2014). Pengaruh city branding dan city image terhadap keputusan berkunjung wisatawan ke Banyuwangi. Jurnal Administrasi Bisnis, 17(1).

Kavaratzis, M. (2005). Branding the city through culture and entertainment. Journal Aesop,5,1-7.

Kavaratzis, M., \& Ashworth, G.J. (2005). City branding: an effective assertion of identity or a transitory marketing trick? Tijdschrift Voor Economische En Sociale Geografie, 96(5), 506-514.

Kavaratzis, M., Braun, E., \& Zenker, S. (2010). My city-my brand: the role of residents in place branding. Paper presented at the 50th European Regional Science Association Congress, Jönköping.

Kokkranikal, J., Cronje, P., \& Butler, R. (2011). Tourism policy and destination marketing in developing countries: The chain of influence. Tourism Planning \& Development, 8(4), 359-380.

Konecnik Ruzzier, M., \& de Chernatony, L. (2013). Developing and applying a place brand identity model: The case of Slovenia. Journal of Business Research, 66(1), 45-52. doi: 10.1016/j.jbusres.2012.05.023 
Kotler, P., \& Gertner, D. (2002). A country as a brand, product, and beyond: A place marketing and brand management perspective. Journal of Brand Management, 9(4), 249-261. doi: 10.1057/palgrave.bm.2540076

LOHO, A.V., \& Braun, E. (2014). City branding the conditions for an effective city branding: The case of Jakarta. Universitas Gadjah Mada.

Lucarelli, A., Kalandides, A., \& Olof Berg, P. (2011). City branding: a state-of-the-art review of the research domain. Journal of Place Management and Development, 4(1), 9-27. doi: 10.1108/17538331111117133

Marsh, D., \& Fawcett, P. (2011). Branding, politics, and democracy. Policy Studies, 32(5), 515-530. doi: 10.1080/01442872.2011.586498

Mason, J. (1996). Qualitative researching. London: Sage.

Matlovicova, K., \& Kormanikova, J. (2014). City brand-image associations detection. Case study of Prague. Psychology and Psychiatry, Sociology and Healthcare, Education, Vol. Ii, 139-146.

Morgan, N., \& Pritchard, A. (2002). Contextualizing destination branding. Destination branding:

Creating the unique destination proposition, 11-41.

Murfianti, F. (2016). Membangun city branding melalui Solo Batik Carnival. Acintya, 2(1).

Oktavia, E., \& Muliawan, S. (2009). Analisa persepsi wisatawan atas destination branding Surabaya sebagai kota wisata melalui slogan sparkling Surabaya. Petra Christian University.

Pakarti, P. (2016). City branding attributes development: Workers and students perspectives. Proceeding ICOBAME.

Pasande, M., \& Suhendra, A. (2017). The strengthening of region competitiveness by implementing city branding in Yogyakarta. Jurnal Bina Praja: Journal of Home Affairs Governance, 9(1), 115-126.

Peirce, S., \& Ritchie, B. W. (2007). National capital branding. Journal of Travel \& Tourism Marketing, 22(3-4), 67-78. doi: 10.1300/J073v22n03_06

Putro, U.S., Mayangsari, L., Siallagan, M., \& Novani, S. (2016). Website as co-created decision support system towards enhanced experience of Solo City tourism. The Asian Journal of Technology Management, 9(2), 88.

Rehmet, J., \& Dinnie, K. (2013). Citizen brand ambassadors: Motivations and perceived effects. Journal of Destination Marketing \& Management, 2(1), 31-38. doi:https://doi.org/ 10.1016/j.jdmm.2013.02.001

Risanto, Y., \& Yulianti, I. (2016). City branding strategy on the evaluation of tourism destination problems in rural areas (evidence from Pasuruan City, Indonesia). Journal of Indonesian Tourism and Development Studies, 4(1), 5-12.

Rukayah, R.S., Wibowo, A.A., \& Wahyuningrum, S.H. (2015). Public participation in branding road corridor as shopping window or batik industry at Pekalongan. Procedia-Social and Behavioral Sciences, 168, 76-86.

Salampessy, H. (2015). Pengaruh city branding terhadap city image dan customer satisfaction serta customer loyalty di Kota Ambon.

Sevcik, T. (2011). Strategic urban narratives: Beyond conventional city branding. Development, 54(3), 343-344. doi: 10.1057/dev.2011.59

Simoes, C., \& Dibb, S. (2001). Rethinking the brand concept: new brand orientation. Corporate Communications: An International Journal, 6(4), 217-224.

Sugiarsono, J. (2009). City branding Bukan Sekedar membuat Logo dan Slogan. Majalah SWA. Jakarta.

Yugiswara, W.W (2016) Analisis online city branding Kota Surabaya sebagai kota jasa dan perdagangan. Tesis Magister. Universitas Airlangga 
Zenker, S., Braun, E., \& Petersen, S. (2017). Branding the destination versus the place: The effects of brand complexity and identification for residents and visitors. Tourism Management, 58, 15-27. doi: 10.1016/j.tourman.2016.10.008

Zouganeli, S., Trihas, N., Antonaki, M., \& Kladou, S. (2012). Aspects of Sustainability in the destination branding process: A bottom-up approach. Journal of Hospitality Marketing \& Management, 21(7), 739-757. doi: 10.1080/19368623.2012.624299

Zenker, S., \& Kalandides, A. (2011). How to catch a city? The concept and measurement of place brands. Journal of Place Management and Development, 4(1), 40-52. doi:10.1108/175383311111171 